\section{Refugiado Ambiental: uma questão Bioética}

\section{Lopes, Adelirian Martins Lara}

Bióloga; Mestre em Bioética pelo Centro Universitário São Camilo/SP; Mestre em Agronomia pela Universidade Estadual de Maringá/Pr; Coordenadora do Curso Técnico em Meio Ambiente em Maringá/Pr da Secretaria de Educação do Estado do Paraná / SEED; Brasil. e-mail: adelirianlopes@gmail.com

PALAVRAS-CHAVE: Refugiado ambiental; Bioética; Vulnerabilidade; Direitos Humanos.

O conceito de refugiado ambiental não é claro, e as alterações climáticas não são os únicos fatores que impactam diretamente esse grupo. Os efeitos de tais fenômenos atmosféricos sobre o meio ambiente e suas consequências sociais tendem a vulnerabilizar esta categoria. Embora sejam eventos locais, suas causas e consequências podem ter origens e repercussões globais. Questões ambientais lograram espaços significativos nos fóruns nacionais $\mathrm{e}$ internacionais nas últimas décadas, e os debates atuais reconhecem a responsabilidade da comunidade internacional para com essa categoria. A Bioética abriu um espaço de reflexão dialógica importante junto a essas questões, e diante da vulnerabilidade a que esta categoria apresenta e seus Direitos Humanos, a reflexão bioética apresenta subsídios a serem inseridos na problemática do refugiado ambiental, justificando sua inserção e permitindo o equacionamento à luz dos referenciais bioéticos. Este estudo tem como objetivos subsidiar a inserção da problemática do refugiado ambiental como uma questão bioética, e, assim, examiná-la à luz dos referenciais bioéticos. Realizou-se uma pesquisa exploratória e descritiva, analisando os aspectos conceituais relativos ao refugiado ambiental, sua vulnerabilidade, seus Direitos Humanos e a legislação vigente a ser correlacionada à Bioética.

\section{REFERÊNCIAS}

[1] AB'SABER, AN; PLANTEMBERG, CM. (orgs.). Previsão de Impactos: o estudo do impacto ambiental no Leste, Oeste e Sul. Experiências no Brasil, na Rússia e Alemanha. São Paulo: EDUSP, 2002.

[2] ADGER, W; KELLY, P. Theory and practice assessing vulnerability to climate change and facilitating adaptation. Netherlands: Klumer Academic Publishers, 2000.

[3] BRANA, GMR; GRISÓLIA, CK. Bio(ética) ambiental: estratégia para enfrentar a vulnerabilidade planetária. Rev. Bioét (Impr.) - 2012; 20(1):41-8.

[4] HOSSNE, WS. Bioética - princípios ou referenciais? O MUNDO DA SAÚDE São Paulo: 2006: out/dez 30 (4): 673 676.
[5] SCHRAMM, FR; REGO, S; BRAZ, M, PALÁCIOS, M. (Org). Bioética: riscos e proteção. Rio de Janeiro: resenha Cad. Saúde Pública, Rio de Janeiro, 22(10): 2253-2259, out, 2006. 